\title{
Understanding the political realities of the mass media in the post-communist context: Poland, Russia, China
}

\author{
Colin Sparks 1 \\ University of Westminster
}

\begin{abstract}
This article, which is based on a paper first delivered at XXIX Congresso Brasileiro de Ciências da Comunicação in Brasília in September 2006, offers an alternative to the dominant theory of transition, which was developed partly in relation to the Latin American experience, and in particular to that of Brasil. In its place, the article resumes the theory of elite continuity developed to explain changes in the central European postcommunist countries in the 1990s. The article tests whether this approach can (a) be extended in time to explain the political realities of the mass media after a decade of social change and (b) whether it can be extended in space to explain the political realities of the mass media in other societies in which the nature of transition has been different. While we can in the Polish case make an argument for a relatively successful transition to democracy, Russia is often seen to have regressed from the immediate post-communist period towards a more authoritarian order, and China, while have experienced rapid and successful marketization, remains a communist dictatorship. The article examines the relationship of the mass media to political life in these three countries and finds a surprising number of similarities. The theory of elite continuity, for which there is now more substantial empirical evidence, explains these processes much better than do available alternatives. In one important respect, the stress upon the necessity of a political revolution to break the hold of the Communist Party, the theory that was developed to explain the central European cases requires modification, since the Chinese experience demonstrates that it is possible for the elite to recompose itself without any substantial political transformation.
\end{abstract}

Key Words: Central Europe, political transition, communism, elite continuity theory, mass media.

\footnotetext{
1 Professor at the University of Westminster, director of CAMRI (Communication and Media Research Institute), co-author of Tabloid Tales: Global Debates over Media Standards (Rowman and Littlefield, 2000); Communism, Capitalism and the Mass Media (Sage Publications,1997), coeditor of Civil Society and Information Society (Purdue University Press, 1994); Communication and Citizenship (Routledge, 1991), among many others.
} 
Resumo: Este artigo, baseado em um trabalho apresentado pela primeira vez no XXIX Congresso Brasileiro da Comunicação em Brasília, em setembro de 2006, oferece uma alternativa à teoria dominante de transição, que foi desenvolvida parcialmente em relação à experiência latino-americana, e em particular à brasileira. No seu lugar, o artigo recupera a teoria de continuidade da elite desenvolvida para explicar mudanças nos países póscomunistas dos anos 90. O artigo verifica se este enfoque pode (a) ser estendido no tempo, para explicar as realidades políticas da mídia de massa depois de uma década de mudança social, e (b) se ele pode estendido no espaço, para explicar realidades políticas da mídia de massa em outras sociedades em que a natureza da transição foi diferente. Enquanto que, no caso polonês, nós podemos identificar uma transição para a democracia relativamente bem sucedida, a Rússia é freqüentemente vista como tendo regredido do período imediatamente pós-comunista em direção a uma ordem autoritária, e a China, embora tendo experimentado uma rápida e bem sucedida mercantilização, permanece uma ditadura comunista. $O$ artigo examina o relacionamento entre mídia de massa e vida política nestes países $e$ encontra um surpreendente número de similaridades. A teoria de continuidade da elite, para a qual existe agora mais evidência empírica, explica muito melhor estes processos do que as alternativas disponíveis. Em um aspecto importante, a ênfase sobre a necessidade de uma revolução política para quebrar o controle do partido comunista, a teoria que foi desenvolvida para explicar os casos da Europa Central requer modificação, uma vez que a experiência chinesa demonstra que é possível para a elite se recompor sem nenhuma transformação política substancial.

Palavras-chave: Europa central, transição política, comunismo, teoria da continuidade da elite, mídia de massa. 


\section{Introduction}

After a decade and half of transformation, the former communist states of central and eastern Europe and the USSR present a very varied picture. There are no agreed criteria whereby we can measure change with any degree of scientific precision, but a survey of a range of different approaches found that there were surprising uniformities across them (Berg-Schlosser 2004). According to this study, it is possible to group the various countries into four categories which run through A (Full Democracy: examples include Poland), B (Almost Liberal Democracy: examples include Bulgaria), C (Electoral Democracy: examples include Russia) to D (Not Democratic: examples include Belarus).

These differences, which are clear and obvious to any observer, are so substantial as to demand explanation, particular since the starting points, although of course nationally-inflected, displayed such strong similarities. Why should it be that a group of countries which 20 years shared a similar if not identical political system, a similar if not identical economic system, and a similar if not identical media system, today demonstrate such a wide range of political, economic and media forms? Quirks of accident and individual influence aside, the problems involved are clearly ones that demand a theoretical answer.

In political science, there is a well-established paradigm for studying the shift from dictatorial to democratic regimes. It is usually known, accurately if inelegantly, as "transitology," and it has been developed to explain a wide spectrum of changes from the end of European fascism in the 1970s through Latin America and Southern Africa to the contemporary problems of post-communism. The most famous, if not the most original, theorist of this school is Samuel Huntington (1991). This approach also dominates much of the writing about media freedom in the former communist countries (Mickiewicz 1999; Gross 2002; Jakubowicz 2003a). This school of thought we term "teleological" in that it effectively believes that the processes it detects are working inevitably towards the end of liberal democracy and that it is possible to measure how far along this road a particular society has progressed. In particular, the school assume that there are two linked processes 
going on - democratization and marketization - which are mutually necessary and complementary (Linz and Stepan 1996, 11).

The problem for this approach is that a gathering body of evidence suggests that the reality of social and political change is much more complicated, and indeed contradictory, than is allowed for by the theoretical framework. As one commentator noted, thinking about these problems should "start by assuming that what is often thought of as an uneasy, precarious, middle-ground between full-fledged democracy and outright dictatorship is actually the most common political condition today of countries in the developing world and the post-communist world" (Carothers 2002, 17-18). In order to account for the range of situations we have to approach the problem from a different perspective.

This paper sets out to do two things. In the first place, it summarises an approach which stresses sociological rather than political or economic phenomena, which was developed by the current author and his colleague some time ago, in order to explain the changes to the media system that were then observable in the countries of the westernmost fringes of the former Soviet empire. It then looks at three examples of postcommunist society and asks whether this approach provides a more convincing account than that offered by transitology, and whether it can be extended to a broader geographical scope than was intended in its first iteration.

\section{The theory of elite continuity}

When studying the complex and protracted evolution of the media in Poland, Hungary, the Czech Republic and Slovakia in the first years after the fall of communism, it quickly became apparent that the course of events was not following the programmes outlined either by the former dissidents who were now in power nor by the legion of consultants from western Europe and the USA who were offering them advice as to how to restructure broadcasting and the press. The very worthy aim shared by almost everyone involved in the early years of transition might be summarised not too inaccurately as an attempt to create newspapers like the New York Times and broadcasters like the BBC (Sparks 2001). In fact, what was emerging were newspapers that were highly partisan in 
their orientation and broadcasters that remained closely aligned with the state rather than the public (Sparks 1998).

The theoretical explanation offered for these realities had seven major components:

1. The events in central and eastern Europe were genuine revolutions. In most cases these revolutions were negotiated between a section of the dissident opposition and the reform wing of the Communist Party, but even in those cases they represented a clean break in the organisation of political life. The monopoly of political power held by the Communist Party was broken both formally and substantially and new political parties were formed and contested for power.

2. There was considerable continuity in both institutions and personnel between the old regime and the new. Institutions like the civil service, the army and the broadcasters remained substantially intact, both in their social position and in terms of their internal structure. In broadcasting, for example, the old state broadcasters were nowhere broken up or privatised. They remained central to the media systems, and they retained a very high proportion of their existing personnel.

3. The shift towards a market economy was a highly political process, with the award of favourable opportunities being very closely connected to political power. The licensing of the new commercial broadcasters was a case in point, where political connections were essential to the winning of franchises.

4. The media institutions that emerged from the process of transition were everywhere strongly influenced by the political elite. This was particularly obvious in the case of the broadcasters, where regulatory bodies were recomposed to follow the shifting results of elections. The media had changed from being one locus of power to being one of the stakes of power.

5. The revolutions were, following this logic, certainly political revolutions, in that they transformed very rapidly the ways in which the countries in question were governed, but they were not social revolutions in that they did not pose any fundamental challenge to the social order in industry or the state machine. 
6. The main dynamic of the revolutions was that it permitted the old elite (roughly, the nomenklatura) to transform itself from one that rested upon the collective ownership of state property, which it guaranteed through its political monopoly, to one that rests on private property, acquired formally or informally through the exercise of political power, but sustained economically in the manner familiar from western capitalist societies.

7. The degree of democratization, if any, is secondary in this model. While the shift to individualised private capital certainly implies a pluralisation of power in the society, it does not automatically follow that this will be articulated through a democratic framework. In the cases studied during the 1990s, there was indeed a considerable degree of democratization, notably in establishing rights to free expression and political association, but theoretically this remained a contingent feature of the new order, not its essence.

This theoretical model, which lays its primary stress upon the social continuity in societies in transition, rather than assuming that the process was essentially one of democratization, provided a good fit to the events in the first decade after the fall of communism in the western-most of the European communist states. The weakest parts of the model were, first, that there was then little sociological evidence as to the personnel shifts in the elite, and secondly that the examples studied did not provide any evidence to test the hypothesis that democratic rule was a contingent factor rather than an integral part of the process. In addition, it was not clear, at least to this author, whether the model could be extended beyond that time frame and those geopolitical parameters to explain more generally the features of transition in a way that appears to elude the dominant paradigm of transitology. In order to test the broader fit of the model, we now turn to the analysis of selected cases of transition from different geographical locations and extend the analysis over a longer time frame.

\section{Poland, Russia, China}

Comparative studies of the media in different countries face at least three major problems: establishing the validity of the chosen examples; limiting the scope of the 
comparison to allow due weight to distinctive national features; and the choice of valid indicators upon which to make the comparison. We will consider these one by one.

The countries selected for this comparison are Poland, Russia and China. The first case is relatively unexceptional, in that it was one of the original subjects of study and it is the largest of the eight former communist countries that have entered the EC. It is rated amongst the highest in the classification of democratic completion discussed above. Russia, again, can be easily justified. It was the core of the old USSR and is the largest and most powerful of the successor states. It is rated in a lower category of democratic completion than Poland. It is fairly easy to see how a fruitful comparison might be made between these two examples.

It is the choice of the third country, China, which is probably the most contentious, since this, obviously, is a society in which there has been no political transition. The Chinese Communist Party still holds a monopoly of political power and vigorously represses any movement that even appears to threaten it. China is, however, a society that has advanced a long way down the road to marketization, particularly, as we shall see, in the case of the mass media. From the point of view of a theory of social continuity, it therefore represents an interesting and valuable comparator to the two European models.

Although the countries had a common starting point in that they shared the main features of a "communist" system of economic, social and political organisation, there were, of course, very important differences. In both Russia and China the regimes could make some nationalist claims to legitimacy, whereas in Poland the Communist Part was widely perceived as having been put in power by Russian tanks. Following directly from that, Poland saw by far the largest and most enduring opposition to communist rule, culminating in Solidarnosc in 1980-81. On another dimension, Poland was, as a consequence of Nazi crimes, an ethnically homogenous society. China has important national minorities. Today's Russia was then embedded in the multi-national USSR, and the pressures to autonomy and independence have been a central feature of its demise. 
While giving due weight to these factors, we can make a comparison between the three cases. There are several dimensions upon which we might make comparisons, but the most obvious one is the extent to which the media carry out the sort of "public sphere" role that is essential to any theory of democratic polity. In operational terms, we might ask to what extent are press and broadcasting able to report and comment freely upon the doings of the political and economic elites in the manner which, at their best, the BBC and the New York Times are able to do.

1. Poland: The official media in Poland were, for most of the communist period, very tightly controlled, but unusually there were some independent media and independent discussion. From the 1950s, the Catholic Church was able to publish its own newspapers, and according to Jakubowicz the opposition was able to have a public presence form the mid-1970s (Jakubowicz 1991, 158-61). With the birth of Solidarnosc, party control over the official press and broadcasting was seriously challenged, and very radical ideas were put forward for democratising the media (Goban-Klas 1994, 165-82; Jakubowicz 1995b 13033). Martial law ended the open movement but, according to one estimate, 2077 underground periodicals were produced during that period. As a consequence, the reformist inside the party were able to enter Round Table discussions with the less extreme opposition and reach an agreement on the transition that included the mass media (GobanKlas 1990).

The media system that emerged out of transition was marked by the survival in legal form of some of the former oppositional papers, notably Gazeta Wyborcza, and the controlled privatization of the existing press (Jakubowicz 1995b). The press which emerged was overwhelmingly 'political' in orientation, despite being dependent upon the market for their survival (many new titles did not survive) (Goban-Klas 1996, 26-28). The results was that the press: 'helps air diverse views and opinions, but usually of party elites, rather than their rank-and-file members or of groups in society in general' (Jakubowicz 2003b, 237). Broadcasting, too, has been strongly marked by political control, particularly of the main regulatory body, the KRRiT. One recent detailed study found that: 'The composition of the KRRit has been systematically politicized, not only in the sense of who appoints its members but, more importantly, in the fact that the members have been more 
or less clearly affiliated to political parties' (Krajewski 2005, 1144). This politicization has proved not to be a passing phase associated with the immediate post-communist period: the 2005 incoming Law and Justice (PiS) led government has changed the broadcasting law and imposed its own appointees to leading bodies (PISS 19 May 2006).

The evidence from what is one of the more successfully democratized postcommunist countries does not show the evolution of an independent media. The media in Poland is certainly highly marketised and plural, and in that it marks a decisive break from the official media of the communist era, but it remains subordinated to elite groups rather than developing a public service orientation.

2. Russia. While there was certainly discontent and dissidence in the USSR, this was not on the scale of Poland and the initiative for social change appears to have emerged from inside the party (White, Gill and Slyder 1993; Ryabov 2004, 175). This led to a sharp division between the reformers (around Yeltsin) and the conservatives (around Ligachev), with Gorbachev attempting to balance in between (Gibbs 1999, 60-61 and 66ff). The media were able to take advantage of this opening to act more independently, and many observers see this as the 'golden age' of the media, who could pursue self-determined journalistic objectives while still enjoying the economic security provided by subsidies (Hagstrom 2000, 200-206; Ryabov 2004, 178).

As the political crisis deepened after 1990, journalists began to take over their papers and the failed coup of 1991, which inaugurated the 'Second Russian Revolution' and led to the end of the USSR, confirmed that process. The newly-liberated press, however, faced serious difficulties. Politically, it owed its position to the Yeltsin victory and thus found itself taking a partisan stance in his support. Economically, costs rose sharply while circulation dropped away very quickly and advertising revenues did not provide adequate compensation. The press faced the real prospect of bankruptcy and one after another the independent newspapers were bought up by the new oligarchs, who used the papers to promote their own interests (Belin 2002a, 140-41; Zassoursky 1999, 162-63; Fadin 2002). In broadcasting, the main state stations fell into the hands of different sections of the political elite and when private broadcasting began in was dependent upon 
the same group of oligarchs as controlled the press. NTV, owned by the oligarch Gusinsky, did engage in some independent reporting, notably of the first Chechen War but in the longer term the convergence of interests between the oligarchs and the Kremlin meant that the 1996 presidential election saw an orchestrated campaign overwhelmingly in favour of Yeltsin.

In the first five years after communism, Russian media changed markedly, but the new-found diversity did not necessarily reflect a greater degree of public service: 'what differentiates this situation from the previous Soviet regime is that various power groups compete in their struggle for resources, thus providing some pluralism of interpretations that sometimes grows into fierce "information wars" (Koltsova 2001, 322-33). To some observers, this seemed a retreat from the last years of communism, since the media's democratizing role had narrowed to that of supporting Yeltsin and the interests of their owners (Ryabov 2004, 182-83).

The period after Yelsin's re-election in 1996 sees a resurrection of the power of the state, certainly with respect to the oligarchs whose fortunes had been established through favourable deals with the weakened state of the previous period. As the state moved to regain its dominant position, it also attempted to re-assert its own, heavily nationalist, definition of the public interest against the private interests of big business. Yeltsin, and his chosen successor Putin, launched a campaign aimed at bringing the media, and in particular television, back under their own close control (Belin 2002b; Lipman andMcFaul 2005, 63-64). The number of media owners has shrunk since the mid-1990s and those that remain are very closely allied with the Kremlin. One consequence is that there has been very little critical reporting of the Second Chechen War, despite its protracted horrors.

The Russian case thus represents, in much more exaggerated form, the same basic tendencies that are present in Poland. The media are now much more plural in ownership and no longer depend on subsidy from the state. They are, however, very clearly in the hands of different sections of the elite, who use their control of media outlets to bargain with each other over the disposal of material assets and political power. Very far from 
representing the interests of the public, they are entirely beholden to the state and its wealthy allies, and they are used as political instruments to sustain the power of that bloc.

3. China. The obvious distinctive feature of China is that the Communist Party, with around 70 million members, is in rude health and continues to enjoy a monopoly of power. At the same time, there has been a very rapid and very successful move in the direction of the market economy, which has progressed very far in the case of the media, both press and television. The party, through the Central Propaganda Department, and its local branches at all levels, continues to control the content of the mass media in considerable detail (Brady 2006). At the same time, as all serious observers would agree, the overwhelming majority of the Chinese media have become increasingly market oriented, indeed market dependent (see, for example, Polumbaum 1994; Zhao 1998; Wu 2000, 57-60; Lee, Zhou and Huang 2006, 582-84).

The route to this state of affairs dates from the initial opening of the economy to elements of the market in 1978. The social changes that this development entailed generated a lively intellectual ferment, particularly amongst journalists, and the reformists in the party encouraged more critical and investigative reporting (Pei 1994, 179-2004; Polumbaum 1990). This period is another one of those 'golden ages' in which journalists enjoyed increasing political freedom while retaining economic security, and in which semiindependent newspapers like the World Economic Herald could be founded (Hsiao and Wang 1990). This ferment culminated in the Tiananmen event of 1989. The studentoriginated demonstrations quickly pulled in other sections of society, including many journalists whose slogans included specific demands for press freedom (Goldman 1994, 33; Gittings 2006, 233). China's 1989, however, unlike Poland's was crushed: the hardliners won the internal party struggle and used force to clear the square. The dissident journalists were fired and the semi-independent papers closed down (Goldman 1994, 33).

The deaths, arrests and beatings did succeed in silencing the internal opposition, but they did not end the process of marketization. Instead, there was a pause up to 1992 and then the process was renewed at an even faster pace. As the economy has grown, so the media have expanded to cater to a vast range of different tastes in much the same way 
as any other media that are driven by advertising and circulation revenues. Alongside domestic and imported entertainment shows there is a well-documented tradition of investigative reporting that survived the crackdown in 1989. This reporting is not merely tolerated by the party, within carefully defined limits, but activity encouraged by it: 'In contrast to Western media portrayal of maverick Chinese journalists challenging the Party line from below and from the outside by discussing hot social issues and official corruption, the most significant step towards the rise of watchdog journalism was initiated at the top of the party's propaganda hierarchy' (Zhao 2004, 55).

The Chinese case, while displaying clear differences, thus has much more in common with the Polish and Russian cases than might strike the casual observer. In all three cases there has been a strong market orientation, which may in fact have gone further in China than in the other two cases. On the other hand, this has not correlated with any clear pattern of democratization. Even in the best case, Poland, the media remain intensely politicized and partisan, and there is little pretence at public service. In Russia, the media is dependent either upon the political elite or upon its closest business associates and they use this control for their own faction purposes. In China, the party retains control of the media and continues to use it for its own ends.

\section{Explaining the changes}

The elite continuity model works very well to explain some, but not all, of the changes in these three cases. The notable failure is in the claim of the necessity of a political revolution to break the power of the Communist Party. The case of China conclusively demonstrates that it is possible to move from state-based property to privately held property while the Communist Party continues to hold a monopoly of political power. The other, partial, failure, lies in the claim that it would be the political elite that influenced the media in this process of change. While that hypothesis is clearly supported by the Chinese case, it is contradicted by the Russian case. True, the economic and political elite are very closely linked in the Russian case, and it is clear that in any power struggle between the two it is the political elite that is triumphant, but they are clearly distinct groups. We are therefore obliged to abandon the hypothesis that a political revolution is essential to the 
ending of communist regimes, and to modify the hypothesis of the influence of the purely political elite to allow for the influence of both political and economic elites.

The group of hypotheses that deal with continuity have, in general, been confirmed. There is clearly strong institutional continuity in the media systems in all three cases. The evidence now available also demonstrates not only was there considerable continuity amongst the media personnel in all three cases but at the same time there was a high degree of elite continuity throughout the societies and these demonstrate a shift from political to economic power. Empirical studies in Europe have as their main finding a high degree of elite continuity (Higley, Culberg and Pakulski 2002/1996). In the case of Poland, a study based on data from 1999 found that the present elite has its roots in the former system' (Wasilewski 2000, 214). The degree of continuity is much more marked in the business than in the political elite, and the new elite were mostly drawn from the second rank of the old nomenklatura, but the degree of continuity is marked in all spheres. In the case of Russia, the degree of continuity was even higher than in Eastern Europe (Steen 2003, 8). By the mid-1990s: 'The distribution of power... appears to have been completed and with the `second Russian revolution’ has come to an end. It was a revolution in which the younger generation of the nomenklatura ousted its older rivals. In effect, it was a bourgeois revolution, in that it led to a change in the socio-political system in the direction of private property and political pluralism' (Kryshtanovskaya and White 1998, 98). In China, too, the evidence is that Party officials have systematically used their power to enrich themselves, their friends and their families (Greenfield and Leong 1997; Lau 1999, 61-68; Ho, Bowles and Dong, 2003). According to one survey, 30 per cent of private entrepreneurs were party members (as opposed to around 5 per cent of the population as a whole) and 'roughly half the privatised firms may have ended up in the control of CCP members' (Pei 2006, 93-4).

One criticism that might legitimately be levelled at the continuity thesis should be noted here. While the thesis is correct in emphasising continuity both of institutions and of elites, it did not give due recognition to the degree to which there was also renewal. It is obvious from the figures above that the new elites, while heavily drawn from the old nomenklatura, also involve new forces who were previously outside of the circles of social 
power. Similarly, we can point to new institutions - Gazeta Wyborcza for example, or the metropolitan dailies in China - that have have developed as a result of the process of transition. What remains unknown, at least for the time being, is the origins and trajectories of these newcomers. In some cases, they will certainly be relatives, friends and business associates of the old elite, but a complete picture would certainly reveal other interesting dynamics of the process of transition.

The hypothesis that democratization was only a contingent element in this process has, rather unfortunately, been confirmed. Even if we accept that Russia would meet the formal 'minimalist' definitions of democracy beloved of transitologists, this is certainly not the case with China. The social nature of transition, the shift from state control of productive property to private control of productive property, and the consequent direct introduction of market relations into the internal working of the economy, is clearly a political process in that it is the state that sets the rules for privatization (or neglects to notice wild privatization - a.k.a. theft). What is not the case, however, is that this requires the formal political processes that are entailed in democratic government: in fact they can be achieved by more or less informal bargaining process. In China, these have been conducted entirely under the auspices of the Communist Party, and in Russia they took place out of public view in the chaotic years around 1991. Poland, and by extension other Eastern European countries, emerge not as the normal pattern of post-communism but as one particularly privileged variant of a process that can, and often does, take darker forms.

\section{Conclusions}

The attempt to extend the continuity thesis to cover a broader group of countries than were considered in the original formulations appears to be predominantly successful. It offers a way of understanding change in general, and change in the media in particular, which allows for the range of observable outcomes and provides an explanation as to why they have such strongly marked common features. To the extent that it must be modified to account for the evidence, it is in a direction that strengthens its explanatory power: the fact that a revolutionary end to communist power, and the consequent installation of democratic procedures, are contingent rather than necessary elements in the move away 
from a communist regime gives greater weight to the dimension of continuity. In contrast, the transitology model provides very little purchase on the cases under review and fails particularly miserably in its assertion that there is a necessary link between democratization and marketization.

The theory of elite continuity thus seems right for extension. So far it has only been applied to cases originating in communism, but these are far from being the only examples of transition that require analysis. Indeed, as we saw, transitology was born from the consideration of quite different cases (notably in Southern Europe and Latin America) and it is logical to examine whether elite continuity theory can successfully challenge transitology on its own ground, so to speak, or whether the process are so distinct as to require different theoretical frameworks in order to explain them.

Finally, the success of the theory of elite continuity raises a very general question of social theory. The majority of accounts, from Brzezinski on the right to Mandel on the left, have held that communism and capitalism are fundamentally antagonistic social systems with nothing significant in common. If, as we have seen, the transition from one to another can be managed, not without great misery, but without great turmoil, then we have to ask whether these theorists were correct. If the main common feature of the transition is that the new elite is derived so substantially from the old elite, then to what extent can it be maintained that the systems are antagonistic? If the communist editor or producer can so easily become the capitalist editor or producer, if the same stations and the same papers can continue to thrive under both regimes, to what extent are we dealing with fundamentally different forms of society? If, as it transpires, we do not need to hypothesise a revolution for one system to be transformed into the other, perhaps it might be better to consider similarities rather than differences? 


\section{References:}

Belin, Laura. 2002a. The Russian Media in the 1990s. Rick Fawn and Stephen White eds. Russia after Communism. London: Frank Cass. 139-60.

Belin, Laura. 2002b. The Kremlin strikes back: The re-assertion of state power over the Russian media. Monroe Price, Andrei Richter and Peter Yu eds. Russian Media Law and Policy in the Yeltsin Decade. The Hague: Kluwer International. 273-302.

Brady, Anne-Marie. 2006. Guiding Hand: The role of the CCP Central Propaganda Department in the current era. Westminster Papers in Communication and Culture, volume 3, number 1. 57-76.

Berg-Schlosser, Bart. 2004. The quality of democracies in Europe as measured by current indicators of democratization and good governance. Journal of Communist Studies and Transition Politics, volume 20, number 1. March 2004. 28-55.

Carothers, Thomas. 2002. The end of the transition paradigm. Journal of Democracy, volume 13, number 1. 5-21.

Fadin, Andrew. 2002. In Russia, Private does not mean Independent: Bankers and Oil Tycoons use the media as a business weapon. Monroe Price, Andrei Richter and Peter Yu eds. Russian Media Law and Policy in the Yeltsin Decade. The Hague: Kluwer International. 257-259.

Gibbs, Joseph. 1999. Gorbachev's Glasnost. The Soviet media in the first phase of perestroika. College Station, Tx: Texas A\&M University Press.

Gittings, John. 2006. The changing face of China: From Mao to the Market. Oxford: Oxford University Press.

Goban-Klas, Tomasz. 1990. Making media policy in Poland. Journal of Communication, volume 40, number 4. 50-55.

Goban-Klas, Tomasz. 1994. The orchestration of the media: The politics of mass communications in Communist Poland and the aftermath. Boulder, Co.: Westview.

Goban-Klas, Tomasz. 1996. Politics versus the Media in Poland: A Game without Rules. The Journal of Communist Studies and Transition Politics, volume 12, number 4, December 1996. 24-41.

Goldman, Merle. 1994. The role of the press in post-Mao political struggle. Chinchuan Lee ed. China's media, media's China. Boulder, Co.: Westview. 23-35.

Greenfield, Gerrard and Apo Leong. 1997. China's communist capitalism: The real world of market socialism. Socialist Register 1997. London: Merlin. 96-122.

Gross, Peter. 2002. Entangled evolutions: Media and democratization in eastern Europe. Baltimore, Ma.: Johns Hopkins University Press.

Hagstrom, Martin. 2000. Control over the media in Post-Soviet Russia. Jan Ekecrantz and Kerstin Olofsson eds. Russia reports: Studies in the Post- 
Communist transformation of media and journalism. Stockholm: Almqvist and Wiksell International. 197-246

Higley, John, Judith Kullberg and Jan Pakulski. 2002 (1996). The persistence of post-communist elites. Larry Diamond and Marc Plattner eds. Democracy after Communism. Baltimore, Ma: John Hopkins University Press. 33-47.

Ho, Samuel, Paul Bowles and Xiaoyun Dong. 2003. "Letting go of the small”: An analysis of the privatization of rural enterprises in Jiangsu and Shandong. Development Studies, volume 39, number 4. April 2003. 1-26.

Huntington, Samuel. 1991. The third wave: Democratization in the late twentieth century. Norman, Ok: University of Oklahoma Press .

Hisao Ching-chang and Yang Mei-rong. 1990. "Don't' force us to Lie": The case of the World Economic Herald. Chin-chuan Lee ed. Voices of China: The interplay of politics and journalism. New York: The Guildford Press. 111-121.

Jakubowicz, Karol. 1991. Musical chairs? The three public spheres in Poland. Peter Dahlgren and Colin Sparks eds. Communication and Citizenship: Journalism and the public sphere in the new media age. London: Routledge. 155-75.

Jakubowicz, Karol. 1993. Stuck in a Groove: Why the 1960s approach to communication democratization will no longer do. Slavko Splichal and Janet Wasko eds. Communication and Democracy. Norwood, NJ: Ablex Publishing Corporation. 33-54.

Jakubowicz, Karol. 1995a. Media as agents of change. David Paletz, Karol Jakubowics and Pavao Novosel eds. Glasnost and After: Media Change in Central and Eastern Europe. Cresskill, NJ: Hampton Press. 19-47.

Jakubowicz, Karol. 1995b. Poland. David Paletz, Karol Jakubowics and Pavao Novosel eds. Glasnost and After: Media Change in Central and Eastern Europe. Cresskill, NJ: Hampton Press. 129-48.

Jakubowicz, Karol. 2003a. Social and media change in Central and Eastern Europe: Frameworks of analysis. David Paletz and Karol Jakubowicz eds. Business as Usual: Continuity and change in Central and Eastern Europe. Cresskill, NJ.: Hampton Press. 3-42.

Jakubowicz, Karol. 2003b. Change in Polish media: How far to go yet? David Paletz and Karol Jakubowicz eds. Business as Usual: Continuity and change in Central and Eastern Europe. Cresskill, NJ.: Hampton Press. 205-42.

Koltsova, Olessia. 2001. News production in contemporary Russia: Practices of power. European Journal of Communication, volume 16, number 3. 315-335.

Krajewski, Andrzej. 2005. Television across Europe: Regulation, policy and Independence - Poland. Open Society Institute ed. Television across Europe: Regulation, policy and independence, Volume 2. Budapest: Open Society Institute

Kryshtanovskaya, Olga and Stephen White. 1998. From power to property: The Nomenklatura in Post-communist Russia. Graeme Gill ed. Elites and leadership in Russian Politics. Basingstoke: Macmillan.81-105. 
Lau, W-K. 1999. The $15^{\text {th }}$ Congress of the Chinese Communist Party: Milestones in China's Privatization. Capital and Class, number 68, Summer 1999. 51-87.

Lee, Chin-chuan. 1994. Ambiguities and contradictions. Issues in China's changing political communication. Chin-chuan Lee ed. China's media, media's China. Boulder, Co.: Westview. 3-20.

Lee, Chin-chuan, Zhou He and Yu Huang. 2005. 'Chinese Party Publicity Inc' conglomerated: the case of the Shenzhen Press Group. Media, Culture and Society, volume 28, number 4, July 2006. 581-602.

Linz, Juan and Alfred Stepan. 1996. Problems of democratic transition and consolidation: Southern Europe, South America and Post-Communist Europe. Baltimore Ma: Johns Hopkins University Press.

Lipman, Masha and Michael McFaul. 2005. Putin and the Media. Dale Herspring (ed.) Putin's Russia: Past imperfect, future uncertain. Lanham, Ma: Rowman and Littlefield. 55-74.

Mickiewicz, Ellen. 1999. Changing channels: Television and the struggle for power in Russia, second edition. Durham, NC: Duke University Press.

Pei, Minxin. 1994. From Reform to Revolution: The demise of Communism in China and the Soviet Union. Cambridge, Mass.: Harvard University Press.

Pei, Minxin. 2006. China's trapped transition: The limits of developmental autocracy. Cambridge, Mass: Harvard University Press.

PISS. 2006. Polish International Satellite Service Report. As reported by BBC Monitoring on 19 May 2006.

Polumbaum, Judy. 1990. The Tribulations of China's Journalists after a Decade of Reform. Chin-chuan Lee ed. Voices of China: The Interplay of Politics and Journalism New York: The Guildford Press. 33-68.

Polumbaum, Judy. 1994. Striving for Predictability: The Bureaucratization of Media Management in China. Chin-chuan Lee ed. China's Media, Media's China. Boulder, Co.: Westview. 113-28.

Ryabov, Andrei. 2004. The Mass Media. Michael McFaul, Nikolai Petrov and Andrei Ryabov eds. Between dictatorship and democracy: Russian post-communist political reform. Washington DC: Carnegie Endowment for International Peace. 174-94.

Sparks, Colin. 2001. Media and democratic society: A survey of post-communist experiences. Margaret Blunden and Patrick Burke eds. Democratic Reconstruction in the Balkans. London: Centre for the Study of Democracy.

Sparks, Colin with Anna Reading. 1998. Communism, capitalism and the mass media. London: Sage.

Steen, Anton. 2003. Political Elites in the New Russia. London: RoutledgeCurzon.

Wasilewski, Jacek. 200o. Polish post-transitional elite. Janina Frentzel-Zagórska and Jacek Wasilewski The Second Generation of Democratic Elite in Central and Eastern Europe. Warsaw: Institute of Political Studies, Polish Academy of Sciences. 197-215. 
White, Stephen, Graeme Gill and Darrell Slider. 1993. The politics of transition: shaping a post-Soviet future. Cambridge: Cambridge University Press.

Wu, Guoguang. 2000. One head, many mouths: Diversifying press structures in reform China. Chin-chuan Lee ed. Power, money and media: Communication patterns and bureaucratic control in cultural China. Evanston, Il: Northwestern University Press. 45-67.

Zassoursky, Ivan. 1999. Russian journalism and the open society. Yassen Zassoursky and Elena Vartanova eds. Media, Communications and the Open Society. Moscow: Moscow State University Faculty of Journalism/IKAR Publishing. 160-66.

Zhao, Yuezhi. 1998. Media, market and democracy in China: Between the party line and the bottom line. Urbana, Il: University of Illinois Press.

Zhao Yuezhi. 2004. Underdogs, lapdogs and watchdogs: Journalists and public sphere problematic in China. Edward Gu and Merle Goldman eds. Chinese intellectuals between the state and the market. London: RoutledgeCurzon. 43-74. 